\title{
Corporate Governance and Accounting Earnings Management: The Case of Tunisia
}

\author{
Azhaar Lajmi (Corresponding author) \\ Assistant professor, GEF2A-Lab, Higher Institute of Management of Tunis \\ University of Tunis, Tunisia \\ E-mail: azhaar_lajmi@yahoo.fr
}

Wided Khiari

Assistant professor, GEF2A-Lab, Higher Institute of Management of Tunis

University of Tunis, Tunisia

Khaled Kanzari

Accountant, Deloitte, Tunisia

Received: October 14, 2019 Accepted: November 29, 2019 Published: December 15, 2019

doi:10.5296/ijafr.v9i4.15616

URL: https://doi.org/10.5296/ijafr.v9i4.15616

\begin{abstract}
This paper aims to test the impact of some corporate governance characteristics on the management of the accounting earnings measured by discretionary accruals. As for the prior research we treat the level of management of accounting earnings as a "proxy" for the quality of the accounting and financial information published by companies. Empirical analysis is based on the modified Jones model (1995) to estimate discretionary accruals and a panel data model applied to a sample of 21 companies listed on the Tunis Stock Exchange (BVMT) over a period of 3 years from 2008 to 2010 . The main findings of the current study reveal that, in the Tunisian context, the affiliation of auditors to a "Big" international network and the independence of the board of directors significantly constrain the practice of managing the accounting earnings and, consequently, they improve the quality of the published result. However, the number of independent members in the audit committee has a negative but not
\end{abstract}


significant impact on the practice of earnings management, whereas the duration of the audit mandate does not affect this practice.

Finally, the control variables taken into account in our study have a significant effect on the quality of the accounting result.

Thus, the results of this study helped to improve our understanding of earnings management in Tunisian companies, with reference to some characteristics of corporate governance.

Keywords: Corporate governance, Earning management, Audit quality, Discretionary accruals

JEL Classification: G32, M42, C23

\section{Introduction}

Financial scandals, notably those of Enron, worldcom (USA), Parmalat (Europe) and Batam (Tunisia) have created a crisis of confidence in the financial markets by affecting the reliability of the financial information and the effectiveness of the governance bodies put in place. Faced with these repeated accounting manipulations, the intervention of an independent and competent external auditor is useful; this will ensure the credibility of the financial information. Moreover, and based on agency theory (Fama and Jensen, 1983), auditing plays a crucial role in reducing information asymmetry between managers and shareholders in order to ensure faithful image of the published financial statements (Jensen and Meckling, 1976). In particular, the external audit, the board of directors and the audit committee are considered, in the Anglo-Saxon as well as the European literature, as encouraging or obliging mechanisms for executives to act in the interests of the shareholders (Lajmi and Gana, 2013).

In that respect, research in financial accounting has undergone significant developments in the late 1970s in light of the work of Watts and Zimmerman (1986) which intended to explain the practices observed and to predict the accounting choices made by managers and standardizers. This line of research is titled the Positive Accounting Theory, borrowing its models from the agency theory and the economic theory of regulation (Casta, 2000). According to Dumontier and Raffounier (1999), positive research in financial accounting aims, on the one hand, to assess the informational content of accounting figures and, on the other hand, to explain accounting decisions based on agency relationships and political costs.

Following these recent events that have shocked the economic world, many academic research projects, particularly Anglo-Saxon and European, conducted in recent years, tend to test and establish a negative relationship between different governance mechanisms and the earnings management, which is most often appreciated by the accounting adjustments or by the discretionary "accruals".

However, still, it seems that the measurement of audit quality is complex and problematic (Broberg et al., 2017) as it cannot be directly observed. Therefore, it has to be measured using different indirect proxies. 
Previous studies show that audit quality reduces profit management activities in companies (Sadiq and Othman, 2017), while some researchers such as Eshleman and Guo (2014), Berglund et al. (2018) show the existence of a correlation between Big 4 auditors and the high audit quality. According to them, the high quality of the auditors limits the manipulation activities at the companies and the fact of not to detect them can harm the reputation of the auditors. However, according to Ajekwe and Ibiamke (2017), Big 4 auditors may not provide higher audit quality than non-Big 4 auditors.

In the same line, Lopes (2018) investigates the relationship between audit quality and earnings manipulation and shows that the level of earnings management is relatively lower among firms audited by Big 4 audit firm. Likewise, using a sample of non - financial listed firms in Pakistan over the period of 2009-2016, Zandi et al. (2019) show that firms audited by big four auditors are more engaged in costly real earnings management activities.

Firnanti et al. (2019) show that free cash flow, return on assets, sales growth and financial leverage have an impact on earnings management. However, there is no significant link between other variables like firm size, managerial ownership, institutional ownership, the presence of an audit committee, board size and audit quality, and earnings management.

Alvarado et al. (2019) addresse earnings management from an international perspective. They analyze particularly whether external auditing reduces earnings managements. They find that external audit is an important mechanism to minimize earnings management. In this sense, the Big Four and auditor specialization help to reduce earnings managements. Moreover, long audit tenure does not contribute to mitigating discretionary accruals.

Saleem and Alzoubi (2018) investigate the relation between audit quality, debt financing, and earnings management in Jordan. They use the cross-sectional version of the modified Jones model, in which discretionary accruals were employed as a proxy for earnings management. Results suggest that audit quality (auditor tenure, size, specialisation, and independence) and debt financing (low debt) diminish the potential of earnings management, and, consequently, improve the financial reporting quality.

Siala Bouaziz and Jarbouia (2019) focuse on investigating the role of an external governance mechanism such as external audit quality based on a sample of French companies. They find that external audit quality plays a moderating role between shareholder activism and earnings management in such a way that it greatly helps to attenuate the relationship in the presence of high-quality external audits.

Within this framework, the main goal of this article is to propose an extension of this line of research to the Tunisian context. The latter is worth to study because it presents many specificities which are assessed on several aspects.

First of all, it can be said that the choice of Tunisian companies is in itself a contribution since the issue of corporate governance has long been ignored in developing countries (Mangena and Tauringana, 2007). Second, transparency and disclosure of information have gained importance from many researchers, who attribute the problem to a major weakness in corporate governance, which has been seen as a factor contributing to the significant 
systematic problems of emerging markets (Standard and Poor's, 2008). Previous research has been conducted primarily in the United States, where investors are relatively well protected. It should be recalled that emerging markets are characterized by a low level of disclosure by companies and by weak protection of minority shareholders (La Porta et al., 1998). Furthermore, in emerging markets, financial information is generally not regulated and the IFRS standard is generally not adopted. Finally, Tunisia is an emerging country, so a comparison of our context with other environments is particularly interesting. This work will enable us to make future study comparison between the results found in the Tunisian context and those obtained in other contexts.

Moreover, this choice is also motivated by the will of the Tunisian legislator to strengthen the financial security by promulgating the law on strengthening the financial security in 2005 , with the aim to promote and improve the transparency of the accounting information as well as the quality of the governance system put in place.

In fact, in Tunisia, the financial scandals that have affected some listed companies lead us to reflect on the context in which these companies operate, and then on the quality and effectiveness of the governance system of these companies. The Tunisian accounting system gives companies a high degree of discretion in the preparation of financial statements and offers them the opportunity and means to manage results (Chabchoub and Mrabet, 2007).

Finally, the objective of this work is to study the factors related to audit quality related to the opportunistic management of results in the Tunisian context. Indeed, we are interested in the aspect of earnings management as a means for the manager to achieve his objectives by publishing a result that is different from the one achieved. Indeed, audit quality is a key factor of the corporate governance system, and can limit the results management process, and thus protect the interests of all stakeholders. To what extent can audit quality influence the opportunistic management of Tunisian companies' results?

This work is organized as follows: section 2 shows first, the research hypotheses from a synthesis of the literature review on the relations between the quality of the external audit, the characteristics of the board of directors and the independence of the audit committee, then second, the earnings management. Section 3 deals with the methodological aspects of the study, namely the sample used, the variables selected as well as their measurements and the econometric model adopted. Section 4 will be devoted to the interpretation of the results, followed by the concluding remarks in section 5 .

\section{Literature Review and Research Hypotheses Development}

Most research that examines the impact of different aspects of the audit on earnings management converges towards a common assumption that the quality of the external audit limits the earnings management (Persakis and Iastridis, 2016). In this sense, the agency's theory states that audit plays a key role in reducing information asymmetry between managers and shareholders or other stakeholders in order to ensure a faithful reflection of the financial information published. 
In this study, we present two attributes of external audit quality, namely the auditor's reputation and the duration of the audit mandate.

Broye (2001) indicates that, the choice of an auditor from the "Big" companies refers to greater reliability of the financial information and makes it possible to limit the risk of undervaluation. Persakis and Iastridis (2016) confirmed the results of the majority of the previous research by showing a negative relationship between the audit quality and the earnings management. Therefore, a better quality of audit implies a good quality of the accounting result. Thus, the first research hypothesis is as follows:

H1: The reputation of the auditor has a positive impact on the quality of the accounting result.

Several authors explain that an excessive relationship between the auditor and his client risks to undermine his independence. Ball et al. (2015) detect a negative relationship between the length of the auditor client relationship and the audit quality. On the other hand, according to Ghosh and Moon (2005), investors see that long audit relationships improve audit quality. Miko and Kamardin (2015) show that the auditor mandate and his belonging to one of the Big4 reduce the manipulation of accounts. Moreover, the majority of the literature confirms this negative effect. Hence our second hypothesis:

H2: The duration of the auditor-audited relationship has a negative impact on the quality of the accounting result.

The agency theory advocates that the board should have a high proportion of independent directors, since the composition of the board can influence its ability to perform its oversight role well. Independent directors are considered to be able to monitor and control the actions of opportunist leaders (Jensen and Meckling, 1976), allowing for more effective protection of shareholder interests.

The empirical result of Shu et al. (2015) indicates that independent members of the board of directors are negatively correlated with the level of earnings management. A more recent study (Wu et al., 2016) shows that the presence of independent directors can significantly inhibit the earnings management. This will ensure a better quality of financial statements for the investors. Therefore, our third hypothesis is formulated as follows :

H3: The independence of the members of the board of directors has a positive impact on the quality of the accounting result

Concerning the audit committee, empirical work shows that companies with an independent audit committee generally publish more reliable financial statements. Miko and Kamardin (2015) show that the characteristics of the audit committee (expertise, independence and size) contribute to considerably reducing the management of the result, thus improving the quality of the accounting result. In this sense, we ask our fourth hypothesis as follows:

H4: The independence of the members of the audit committee has a positive impact on the quality of the accounting result. 


\section{Research Methodology}

The sample used includes 21 companies listed on The Tunis Stock Exchange (BVMT) over a period of 3 years from 2008 to 2010.

In our study, we have identified the level of management of accounting earnings as a "proxy" for the quality of the accounting and financial information published by companies. This choice is motivated, first and foremost, by the fact that the accounting result represents the main source of information helping the various stakeholders to evaluate the financial situation as well as the performance of the company. Secondly, the literature on earnings management is based on the assumption that it is possible to evaluate the management of the result. In this respect, accruals are used as a measure of this practice.

Various measures of discretionary accruals are used by the literature to estimate the management of accounting earnings. The most commonly used models are the Jones model (1991), the margin model of Peasnell et al. (2000), the model of Jeter and Shivakumar (1999) and the model of Dechow et al. (2003). As part of our research, we use discretionary accruals for detecting manipulation of accounting earnings.

As a first step, we calculate the total accruals for each firm $\mathrm{i}$ and year $\mathrm{t}$ according to the following formula:

Totals Accrual $\mathrm{i}_{\mathrm{i}, \mathrm{t}}=$ net profit $\mathrm{i}_{\mathrm{t} \mathrm{t}^{-}}$operating cash flow

In a second step, we estimate discretionary accruals using Jones' (1991) cross-sectional model. In order to assess the sensitivity of our results to the measurement problems of discretionary accruals and like most research on this issue, we apply two approaches to the Jones model: (1) the modified version controlling the variations of the trade receivables (Dechow et al., 1995) and (2) the enriched modified version incorporating the impact of operating cash flows at the level of the estimation of the model parameters (Jeter and Shivakumar's cash flow model, 1999).

\subsection{The Modified Jones Model (1995)}

Dechow et al. (1995) modified Jones' (1991) model by subtracting changes in trade receivables from the change in consolidated net sales. As a result, the increase in sales with no immediate counterpart in trade receivables explains the discretionary accruals. This way, the manipulation of payment deadlines to increase the result will be neutralized.

Jones' model modified by Dechow et al. (1995), is as follows:

$$
\text { TACi,t/ TAi,t-1= a+b1( } \triangle \text { TURN- } \triangle \text { ACR)i,t / TAi,t-1) + b2 (FIXAit/ TAi,t-1) + ui,t }
$$

\subsection{The Cash Flow Model (1999)}

Jeter and Shivakumar (1999) propose a model that takes into account cash flow. This model integrates operating cash flows into the model of Dechow et al. (1995) and it is as follows: 
TACi,t/ TAi,t-1= a+b1( $\Delta$ TURN- $\triangle$ ACR)i,t / TAi,t-1) + b2 (FIXAit/ TAi,t-1)

$$
\text { + b3 (OCFi,t/ TAi,t-1) + ui,t }
$$

With:

$\mathrm{TAC}_{\mathrm{i}, \mathrm{t}}$ : Total accruals of year $\mathrm{t}$ for firm $\mathrm{i}$. For our case, we will calculate total accruals using the cash flow method, also known as the "direct method", which assumes that the accruals are the difference between the result and the cash flow from operations.

$\mathrm{TA}_{\mathrm{i}, \mathrm{t}-\mathrm{l}}$ : Total assets of firm $\mathrm{i}$ at the end of year $\mathrm{t}-1$.

FIXA $_{i, t}:$ Fixed assets of the firm $i$ at the end of the year $t$.

$\Delta$ TURN $_{\mathrm{i}, \mathrm{t}}$ : Turnover of year $\mathrm{t}$ - turnover of year $\mathrm{t}-1$ for firm $\mathrm{i}$.

$\triangle \mathrm{ACR}_{\mathrm{i}, \mathrm{t}}$ : the difference between the amount of accounts receivables in year $\mathrm{t}$ and the amount of accounts receivables in year $\mathrm{t}-1$ for firm $\mathrm{i}$.

$\mathrm{OCF}_{\mathrm{i}, \mathrm{t}}=$ Operational cash flow $(\text { Current result before taxes }-\mathrm{TAC})_{\mathrm{i}, \mathrm{t}}$

$\mathrm{U}_{\mathrm{i}, \mathrm{t}}$ : the error term during the year $\mathrm{t}$ for the firm $\mathrm{i}$.

The discretionary accruals, denoted $\mathrm{DAC}_{\mathrm{i}, \mathrm{t}}$ are finally obtained by the difference between the total accruals of each firm and the supposed non-discretionary accruals :

$$
\mathrm{DAC}_{\mathrm{i}, \mathrm{t}}=\mathrm{TAC}_{\mathrm{i}, \mathrm{t}} / \mathrm{TA}_{\mathrm{i}, \mathrm{t}-1}-\mathrm{NDAC}_{\mathrm{i}, \mathrm{t}} / \mathrm{TA}_{\mathrm{i}, \mathrm{t}-1}
$$

With

$$
\mathrm{NDAC}_{\mathrm{i}, \mathrm{t}} / \mathrm{TA}_{\mathrm{i}, \mathrm{t}-1}=\mathrm{a}\left(1 / \mathrm{TA}_{\mathrm{i}, \mathrm{t}-1}\right)+\mathrm{b} 1\left[(\Delta \mathrm{TURN}-\Delta \mathrm{ACR}) / \mathrm{TA}_{\mathrm{i}, \mathrm{t}-1}\right]+\mathrm{b} 2\left(\mathrm{FIXA}_{\mathrm{i}, \mathrm{t}} / \mathrm{TA}_{\mathrm{i}, \mathrm{t}-1}\right)
$$

Thus:

$$
\mathrm{DAC}_{\mathrm{i}, \mathrm{t}}=\mathrm{TAC} / \mathrm{TA} \mathrm{i}_{\mathrm{i}, \mathrm{-}-1}-\left[\mathrm{a}\left(1 / \mathrm{TA}_{\mathrm{i}, \mathrm{t}-1}\right)+\mathrm{b}_{1}(\Delta \mathrm{TURN}-\Delta \mathrm{ACR}) / \mathrm{TA}_{\mathrm{i}, \mathrm{t}-1}+\mathrm{b}_{2}\left(\mathrm{FIXA}_{\mathrm{i}, \mathrm{t}} / \mathrm{TA}_{\mathrm{i}, \mathrm{t}-1}\right)\right](3)
$$

In our study, the regression error term (1) for total accruals represents the estimate of the discretionary accruals.

In order to use the discretionary component of the most appropriate accounting result in the estimation model (the modified Jones model or the cash flow model), we compared the R2 coefficients of determination of the two models to identify the model that explains better the discretionary accruals.

Table 1. Choice of the estimation model for discretionary accruals

\begin{tabular}{llll}
\hline Accruals & $\mathrm{N}$ & F-test (critical value of F) & adjusted R2 \\
\hline Approach 1 & 63 & $27.90(2,7012 \mathrm{E}-09)$ & $46 \%$ \\
\hline Approach 2 & 63 & $105.88(1,01595 \mathrm{E}-23)$ & $83.53 \%$ \\
\hline
\end{tabular}




\section{Mll Macrothink}

International Journal of Accounting and Financial Reporting

ISSN 2162-3082

2019, Vol. 9, No. 4

As shown in Table 1, the results indicate that the explanatory power of Approach $2(83.53 \%)$ is higher than that of Approach 1. Therefore, we will opt for the cash flow model for the rest of our work.

We note that the definitions and measures of the variables used in this work are summarized in the Annex.

\section{Empirical Results}

We recall, at this level, that the objective of our work is to examine the impact of certain corporate governance mechanisms on the quality of the accounting result published by listed Tunisian companies. The econometric model used takes the following form:

$$
\begin{aligned}
\text { DAC }_{\text {it }} & =\alpha_{0}+\alpha_{1} \text { REPUT }_{\text {it }}+\alpha_{2} \text { SENIOR }_{i t}+\alpha_{3} \text { INDAC }_{\text {it }}+\alpha_{4} \text { INDBD }_{\text {it }}+\alpha_{5} \text { SIZBD }_{\text {it }} \\
& +\alpha_{6} \text { INDEBT }_{i t}+\alpha_{7} \text { SIZE }_{i t}+\alpha_{8} \text { PERF }_{i t}+\varepsilon_{i t}
\end{aligned}
$$

To study the normality of the residues, the application of Kurtosis tests or flattening coefficient and Skewness or asymmetry cofficient, is necessary.

Table 2. Normality of residuals indices

\begin{tabular}{lllll}
\hline variable & $\mathbf{N}$ & Pr (Skewness) & $\operatorname{Pr}($ Kurtosis) & Prob $>$ Chi2 \\
\hline residual & 63 & 0.376 & 0.0302 & 0.0601 \\
\hline
\end{tabular}

The results in Table 2 show that the Skewness and Kurtosis index values are close to zero, so the probability of the test is greater than $0.05(0.0601)$. In this case, we will keep the null hypothesis of normality of the residues. Therefore, the first hypothesis of normality of the residues is accepted. The results obtained are presented in Table 3.

Table 3. Estimation results of the multivariate regression model

\begin{tabular}{llll}
\hline & Coefficient & $\mathrm{Z}$ & Signification \\
\hline Constant & -0.5096 & -2.78 & $0.003 * * *$ \\
REPUT & -0.0402 & -1.97 & $0.032^{* *}$ \\
SENIOR & 0.0061 & 1.18 & 0.105 \\
INDAC & -0.0105 & -0.49 & 0.524 \\
INDBD & -0.0985 & -2.28 & $0.022^{* *}$ \\
SIZBD & 0.0249 & 1.89 & $0.042^{* *}$ \\
INDEBT & -0.1735 & -4.87 & $0.000^{* * *}$ \\
SIZE & 0.0331 & 2.64 & $0.019 * *$ \\
PERF & -0.2203 & -4.02 & $0.000 * * *$ \\
\hline
\end{tabular}




\begin{tabular}{ll} 
R2 within & 0.0378 \\
R2 Between & 0.8153 \\
\hline Wald Chi (2) & 56.33 \\
value & $0.0000^{* * *}$
\end{tabular}

$* * *$ : significant at the level $0.01 ; * *$ : significant at the level 0.05

The analysis in Table 3 relating to the coefficients of determination R2 allows us to assess the quality of the model of our study. Specifically, referring to the R2 between value, we conclude that $81.53 \%$ of the variability in the level of earnings management between Tunisian firms is explained by the quality of the external audit (auditor's reputation, seniority the audit mandate), the independence of the members of the board of directors and the audit committee as well as the other control variables of our study (level of indebtedness, size of the board of directors and company's size).

According to the R2 Within, the error term of the model contributes in the explanation of the dependent variable with $3.78 \%$. As for the Wald Chi (2) statistic, it is equal to 56.33 and is highly significant at the $1 \%$ threshold $(p$-value $=0.000)$.

The results of the multivariate analysis show that the auditor's reputation (REPUT) seems to have a link with the level of earnings management in listed Tunisian companies. Indeed, the coefficient of this variable is negative and statistically significant at the $5 \%$ threshold $(\mathrm{p}=$ 0.032). This first result shows that the membership of the auditors in a Big4 international network limits the practice of earnings management and consequently improves the quality of the accounting result published by the companies. This can be justified by the fact that the Big4 provide better quality services. This result is consistent with the results of Omri et al. (2009) in the Tunisian context. Therefore, hypothesis H1 of our research is confirmed.

Nevertheless, the variable related to the duration of the audit mandate (SENIOR) does not seem to have any significant effect on the discretionary accruals (DAC). According to the results obtained, this variable reports a positive and statistically insignificant coefficient $(\mathrm{p}=$ 0.105). The result can be explained by the fact that a long audit relationship may be detrimental to the independence of the auditor and therefore may develop personal links between the two parties, which may lead to a limited vigilance of the auditor. Given the insignificant influence of the seniority of the auditor on the level of management of the accounting earnings and consequently on the improvement of the quality of the financial information, the hypothesis $\mathrm{H} 2$ is not confirmed.

In addition, the independence of the board of directors (INDBD) shows a negative and significant coefficient at the $5 \%$ threshold ( $\mathrm{p}$-value $=0.022$ ). This result implies, in accordance with what is predicted, that the presence of external directors on the Board constraints the practice of managing accounting earnings in listed Tunisian companies. Therefore, hypothesis H3 of our research is confirmed. This last result supports the predictions of the agency theory which supposes that the presence of increasingly higher external administrators on the board is likely to improve the control exercised by them and 
limit the opportunist behavior of the leaders (Fama and Jensen, 1983). In addition, this result corroborates those reached by Peansell et al. (2000), and Xie et al. (2003) who found a negative and significant impact between board independence and earnings management practice.

In addition, it appears that the independence audit committee variable (INDAC) has no impact on the level of management of accounting earnings. Despite the fact that the sign of the relationship is consistent with our prediction, the impact found is not statistically significant $(Z=-0.49$ and $p=0.524)$. As a result, hypothesis $\mathrm{H} 4$ is not confirmed. This result can be explained by the fact that the practice of audit committees is relatively new in Tunisia, it became mandatory for some categories of companies by the law on strengthening financial security in 2005. This law does not require a particular composition of the committee by independents like the SOX Act in the United States which requires that the audit committee to be composed exclusively by independent directors.

With respect to control variables, we note that the debt variable (INDEBT) has a negative and significant effect on discretionary accruals at $1 \%$ threshold $(Z=-4.87, p=0.000)$. As a result, companies are encouraged to adopt a conservative and non-opportunistic accounting stance. This result is consistent with the result found by Piot and Janin (2004).

Contrary to the hypothesis of the positive business size theory, which predicts a negative relationship between discretionary accruals (DAC) and firm size (SIZE), we obtained the opposite effect, namely a positive and significant impact $(Z=2.64, p=0.019)$. This result corroborates that of Jeanjean (2001) in the French context.

The size of the board (SIZBD), is a control variable measured by the total number of directors sitting on the board, shows a positive and significant coefficient at the $5 \%$ threshold ( $p$-value $=0.042$ ). It seems from this result that the larger the size of the board, the greater the discretionary component of the accounting result will be. This result can be explained by the fact that a large board makes the process of communication, coordination of efforts and supervision more cumbersome and prevents the synchronization of efforts by the directors as part of their missions.

Finally, the performance, on the contrary, has a negative and significant influence $(Z=-4.02$; $\mathrm{p}=0.000$ ) on results management. Indeed, several studies indicate an upward trend in earnings management among companies with poor accounting performance. This means that, in a context of poor performance, executives can choose, as the case may be, to record a maximum of losses ("big laundry"), or on the contrary, to manage the results upwards in order to mask the firm's difficulties. This result is consistent with the prospect theory (Kahneman and Tversky, 1979). Managers of companies that are loss-making (or less profitable) are more likely to engage in earnings management. This corresponds to risk-seeking behavior as it provides an incentive for them to manage reported earnings. In this case, the incentive comes from improving the company's image to its different stakeholders and reducing the visibility of this poor performance. More specifically, the motivations that we are testing are the willingness to avoid an accounting loss and the willingness to avoid a decline of the accounting results. 


\section{Conclusion}

In this research, we have tried to understand the behavior of Tunisian companies listed on the Tunis Stock Exchange over a period of three years, from 2008 to 2010, in terms of earnings management. We assume that earnings management can be affected by some characteristics of corporate governance.

The main results we have reached show that, in the Tunisian context, the affiliation of auditors to a "Big" international network and the independence of the board of directors significantly constrain the practice of managing the accounting earnings and, consequently, they improve the quality of the published result.

However, the number of independent members in the audit committee has a negative but not significant impact on the practice of earnings management, whereas the duration of the audit mandate does not affect this practice.

Finally, the control variables taken into account in our study have a significant effect on the quality of the accounting result.

Thus, the results of our study helped to improve our understanding of earnings management in Tunisian companies, with reference to some characteristics of corporate governance.

These results reflect the overall state of specific governance in Tunisian context. Indeed, the difference in our results from those found in the US and European context can be explained by the specificity of the Tunisian environment especially in the legal framework and the degree of financial market development. Our research is in a relatively new Tunisian financial market, which is also restricted, very little exposed to the outside and therefore underdeveloped compared to its European and American counterparts, but this market has experienced some major financial scandals that generated a crisis of confidence in the financial statements of companies and consequently in the audit quality provided to these companies. These scandals have prompted Tunisian authorities to strengthen the rules of corporate governance (Law No. 2005-96) that are still likely to be circumvented by those close to power up before the revolution.

This study presents many contributions distinguishing it from other studies. It enriches the theme of accounting earning management by examining the Tunisian context for which, contrary to European and American works, the topic of accounting earning management has given rise to very little research. It is worth to remember that our choice of the Tunisian context is motivated by different reasons. First, this context is interesting to analyze insofar as it presents particularities in terms of governance. In fact, the crisis of confidence sparked by the BATAM affair gave birth to law 2005-96 on the security of financial relations. This law has highlighted two fundamental aspects: strengthening corporate governance rules and improving the quality of external auditing.

The Tunisian context is also distinguished by the strong legal protection of the independence of the auditor (three-year mandate renewable, double auditing mandatory for the certification of consolidated accounts and separation of audit and advisory activities, etc.), which 


\section{Mll Macrothink}

International Journal of Accounting and Financial Reporting

ISSN 2162-3082

2019, Vol. 9, No. 4

increases the ability of firms to resist managerial pressures and limit the opportunism of managers.

The above analysis thus confirms the particularity of the Tunisian environment, which appears to be an interesting and conducive framework to show how governance mechanisms, notably the audit quality, affect the management of accounting earning.

These results contribute to the growing literature on audit quality by showing a direct relation between corporate governance characteristics and especially audit quality and earnings management. The results also add to the prior studies examining discretionary accruals and especially in developing countries like Tunisia. In particular, our results show that Tunisian managers are involved in earnings management to avoid losses and earnings decreases. The results are not surprising and involve the Tunisian context characterized by the owner-largest shareholder and the concentrated bank-dominated system; managers participate in firm management and influence most of the management decisions. However, like any research work, our study present some limits related to sample used and the corporate governance variables. Indeed, it is difficult to generalize the results of the present research.

In continuation of this research, it would be appropriate to review the validity of the assumptions of our study on a larger sample and over a longer period and to insert other variables explaining the earnings management. Subsequently, the consideration of other governance features such as the duality of the board of directors, the expertise and diligence of the audit committee could be the subject of further research. In addition, the audit fees, the co-audit or the auditor's specialization could be adopted to approach the audit quality. These different measures could be considered simultaneously for the construction of a composite index, in order to approach the external audit quality. Also, a careful investigation of additional control variables of financial statements is needed for further research. It seems also important that links between earnings management measured through the distribution of reported earnings and audit quality should be deeply and further studied.

\section{References}

Ajekwe, C. C. M., \& Ibiamke, A. (2017). The association between audit quality and earnings management by listed firms in Nigeria. European Journal of Accounting, Auditing and Finance Research, 5(4), 1-11.

Alvarado, N. R., de Fuentes, P., \& Laffarga, J. (2019). Do auditors mitigate earnings management during economic crisis?. Revista de Contabilidad Spanish Accounting Review, 22(1), 6-20.

Ball, F., Walker, J., \& Wells, P. (2015). Is audit quality impacted by auditor relationships?. Journal of Contemporary Accounting and Economics, 11(2), 166-181.

Broberg, P., Tagesson, T., Argento, D., Gyllengahm, N., \& Mårtensson, O. (2017). Explaining the influence of time budget pressure on audit quality in Sweden. Journal of Management and Governance, 21(2), 331-350. 


\section{$\triangle 1$ Macrothink}

International Journal of Accounting and Financial Reporting

ISSN 2162-3082

Broye, G. (2001). Choix des cabinets d'audit et évaluation des titres introduits au second marché. Comptabilité-Contrôle-Audit, 7(2), 105-124.

Casta, J. F. (2000). Théorie positive de la comptabilité. Encyclopédie de la comptabilité, du contrôle de gestion et de l'audit. Edition Economica, 1223-1232.

Chabchoub, M., \& Mrabet, M. (2007, May). Gestion uu résultat et introduction en bourse: cas des entreprises tunisiennes. Comptabilité et Environnement.

Dechow, P., Sloan, R., \& Sweeney, A. (1995). Detecting earnings management. The Accounting Review, 70(2), 193-226.

Dechow, P. M., Richardson, S. A., \& Tuna, I. (2003). Why are earnings kinky? An examination of the earnings management explanation. Review of Accounting Studies, 8(2-3), 355-384.

Dumontier, P., \& Raffounier, B. (1999). Vingt ans de recherche positive en comptabilité financière. Comptabilité-Contrôle-Audit, 5, 179-197.

Fama, E. F., \& Jensen, M. C. (1983). Separation of ownership and control. Journal of Law and Economics, 26(2), 301-325.

Firnanti, F., Pirzada, K., \& Budiman, B. (2019). Company characteristics, corporate governance, audit quality impact on earnings management. Accounting and Finance Review, 4(2), 43-49.

Ghosh, A., \& Moon, D. (2005). Auditor tenure and perceptions of audit quality. Acconting Review, 80(2), 585- 612.

Jeanjean, T. (2001). Incitations et contraintes à la gestion du résultat. Comptabilité- ContrôleAudit, 1(7), 61-76.

Jensen, M., \& Meckling, W. (1976). Theory of the firm: managerial behaviour, agency costs and ownership structure. Journal of Financial Economics, 3(4), 305-360.

Jeter, D., \& Shivakumar, L. (1999). Cross-sectional estimation of abnormal accruals using quarterly and annual data: effectiveness in detecting event-specific earnings management. Accounting and Business Research, 29(4), 299-319.

Jones, J. (1991). Earnings management during import relief investigations. Journal of Accounting Research, 29(2), 193-228.

Kahneman, D., \& Tversky, A. (1979). Prospect Theory: An Analysis of Decision Under Risk. Econometrica, 47(2), 263-292.

La Porta, R., Lopez-De-Silanes, F., Shliffer, A., \& Vishny, R. (1998). Law and finance. Journal of Political Economy, 106(6), 1113-1150.

Lajmi, A., \& Gana, M. (2013). Audit committee and external audit quality: substitution or complementarity? Empirical evidence on Euronext Brussels. International Journal of Financial Management Research and Development, 3(2), 22-38. 


\section{Macrothink}

International Journal of Accounting and Financial Reporting

ISSN 2162-3082

2019, Vol. 9, No. 4

Mangena, M., \& Tauringana, V. (2007). Disclosure, corporate governance and foreign share ownership on the Zimbabwe stock exchange. Journal of International Financial Management and Accounting, 18(2), 53-85.

Miko, N. U., \& Kamardin, H. (2015). Impact of audit committee and audit quality on preventing earnings management in the pre- and post- Nigerian corporate governance code 2011. Procedia - Social and Behavioral Sciences, 172, 651-657.

Omri, A., Hakim, F., \& Triki, F. (2009). Impact de l'audit externe sur la qualité du résultat comptable: cas des entreprises tunisiennes cotées. Revue Gouvernance, 6(2), 1-19.

Peasnell, K. V., Pope, P. F., \& Youn, S. (2000). Accrual management to meet earnings targets: UK evidence pre-and post-Cadbury. British Accounting Review, 32(4), 415-445.

Persakis, A., \& Iatridis, G. E. (2016). Audit quality, investor protection and earnings management during the financial crisis of 2008: An international perspective. Journal of International Financial Markets. Institutions and Money, 41, 73-101.

Saleem, E., \& Alzoubi, S. (2018). Audit quality, debt financing, and earnings management: Evidence from Jordan. Journal of International Accounting, Auditing and Taxation, 3à, 69-84.

Shu, P. G., Yeh, Y. H., Chiu, S. B., \& Yang, Y. W. (2015). Board external connectedness and earnings management. Asia Pacific Management Review, 20(4), 265-274.

Siala Bouaziz, S., \& Jarboui, A. (2019). The Moderating effect of audit quality on the relation between shareholder activism and earnings management: Evidence from France. Contemporary Economics, 13(1), 63-78.

Watts, R. L., \& Zimmerman, J. (1986). Agency problems, auditing, and the theory of the firm, some evidence. Journal of Law and Economics, 26, 613-633.

Wu, S., Chen, C. M., \& Lee, P. C. (2016). Independent directors and earnings management: The moderating effects of controlling shareholders and the divergence of cash-flow and control rights. North American Journal of Economics and Finance, 35, 153-165.

Zandi, G., Sadiq, M., \& Mohamad, S. (2019). Big-four auditors and financial reporting quality: evidence from Pakistan. Humanities and Social Sciences Reviews, 7(2), 369-375.

\section{Note}

Note 1 . The performance was apprehended by the neperian logarithm of the Tobin'Q. The theory defines this ratio as the market value of the liabilities and shareholders equity divided by the replaced value of fixed assets. Although it has the advantage of combining stock market return and accounting return, it's difficult to use in a study using non American companies since it's the only contry that requires companies to disclose the replacement cost of capital assets. For these reasons, we will use an approximation of this ratio. In this work, the Tobin' $Q$ is calculated by dividing market capitalization by total asstes. A ratio higher than 
the unit means that the firm total assets anticipated by the market is higher than weighted average cost of capital. This means that the firm creates value, and vice versa.

\section{Appendix}

Definitions and measurements of independent and control variables

\begin{tabular}{|c|c|c|c|}
\hline & Variables & Codification & Measures \\
\hline \multirow{5}{*}{$\begin{array}{l}\text { Independent } \\
\text { variables }\end{array}$} & $\begin{array}{l}\text { Reputation of the } \\
\text { external auditor }\end{array}$ & REPUT & $\begin{array}{l}1 \text { si Big4 } \\
0 \text { sinon }\end{array}$ \\
\hline & $\begin{array}{l}\text { Seniority of the } \\
\text { external auditor }\end{array}$ & SENIOR & $\begin{array}{l}\text { number of years between the first } \\
\text { appointment of the auditor and the last } \\
\text { fiscal year }\end{array}$ \\
\hline & $\begin{array}{l}\text { Independence of the } \\
\text { audit committee }\end{array}$ & INDAC & $\begin{array}{l}\% \text { of external directors }=\text { number of } \\
\text { external directors } / \text { total number of } \\
\text { directors on the committee }\end{array}$ \\
\hline & Independence of the & INDBD & $\begin{array}{l}\% \text { of external directors }=\text { number of } \\
\text { external directors } / \text { total number of } \\
\text { directors in the board }\end{array}$ \\
\hline & & & $\begin{array}{l}\text { O’Sullivan (2000), Piot (2005), Lajmi } \\
\text { and Gana (2013), Dwekat et al. (2018) }\end{array}$ \\
\hline \multirow[t]{4}{*}{$\begin{array}{l}\text { Control } \\
\text { variables }\end{array}$} & The board size & SIZBD & $\begin{array}{l}\text { Total number of the directors in the } \\
\text { board }\end{array}$ \\
\hline & $\begin{array}{l}\text { Level } \\
\text { indebtedness }\end{array}$ & INDEBT & $\begin{array}{l}\text { The debt ratio }=\text { Total debts to } \mathrm{LT} / \\
\text { Total assets }\end{array}$ \\
\hline & The company size & SIZE & Ln (Total assets) \\
\hline & Performance & PERF & Ln $(\mathrm{Q})$ (Note 1$)$ \\
\hline
\end{tabular}

\section{Copyright Disclaimer}

Copyright for this article is retained by the author(s), with first publication rights granted to the journal.

This is an open-access article distributed under the terms and conditions of the Creative Commons Attribution license (http://creativecommons.org/licenses/by/4.0/) 